\title{
Management responses of three species of declining sparrows in tallgrass prairie
}

\author{
SCOTT R. SWENGEL
}

\section{Summary}

Three species of declining grassland songbirds were counted in June transects at 42 south-western Missouri (U.S.A.) prairie preserves managed three different ways: biennial July haying, spring burning on a 1-4 year cycle, and sites both burned and hayed every 2-4 years. Hayed prairies had twice as many Henslow's Sparrows Ammodramus henslowi as burned prairies and 2.5 times as many as sites which had been burned and hayed. Hayed prairies had $59 \%$ more Grasshopper Sparrows A. savannarum and $14 \%$ more Dickcissels Spiza americana than burned prairies. Fired and hayed sites had $34 \%$ higher detection rates of Grasshopper Sparrows than sites only burned and similar numbers of Henslow's Sparrows and Dickcissels as burned sites. The three species summed were $60 \%$ more abundant in hayed as in fired or fired and hayed prairies. Henslow's Sparrows increased and Grasshopper Sparrows decreased with time since the last management. Grasshopper Sparrows peaked one year earlier after haying than after burning. Dickcissels did not vary by time since last management. Henslow's Sparrows and Dickcissels were significantly more abundant in larger prairies. Preserve management for these three prairie birds should emphasize biennial to triennial mid-summer haying, instead of burning.

\section{Introduction}

Tallgrass prairie has been $99 \%$ destroyed since European settlement (Solecki and Toney 1986, Hands et al. 1989). This catastrophic habitat loss and the intensification of rowcrop agriculture are important causes for the alarming declines of many prairie birds (Sample 1989, Herkert 1994a,b). Birds nesting in grasslands and ground-nesting birds in eastern and central North America have the greatest community-wide declines of any Nearctic biome and nesting guild, respectively (Peterjohn et al. 1994, 1995, Knopf 1995). During 1966-93, the North American Breeding Bird Survey (BBS) indicated that Henslow's Sparrows Ammodramus henslowi declined $91 \%$ rangewide, Grasshopper Sparrows Ammodramus savannarum 66\%, and Dickcissels Spiza americana 39\% (Peterjohn et al. 1994). Henslow's and Grasshopper Sparrows are among the fastest declining North American songbirds (Peterjohn et al. 1994). Henslow's Sparrow is endangered in Canada, globally listed as near-threatened (Collar and Andrew 1988), and may be among the Nearctic birds most likely to go extinct (Butcher 1989).

Henslow's Sparrows are short-distance migrants, wintering primarily in the southern U.S.A., while Grasshopper Sparrows winter from the southern U.S.A. 
to northern South America (Sibley and Monroe 1990). Dickcissels winter primarily in northern South America (Fretwell 1973). These three fringillids ("sparrows", although the Dickcissel is in tribe Cardinalini and not a sparrow in the strictest sense) have undergone long-term range contraction in the eastern part of their ranges. Henslow's Sparrow is also contracting from the north, with numerous populations disappearing (IIlinois Natural History Survey 1983, Hands et al. 1989).

Although most prairie preserves were grazed or hayed for decades prior to their purchase as reserves, nearly all were thereafter managed with cool-season fire (average rotation 2-6 years). Most prairie managers consider fire the dominant prehistoric process creating and maintaining prairie (e.g. Sauer 1950, Hulbert 1973). Others assert that the prehistoric prairie was maintained primarily by grazing (e.g. England and DeVos 1969), like today's African Serengeti (McNaughton 1985). The historical evidence is inadequate to substantiate frequent and pervasive prairie fires, although most lightning fires occurred during summer (Higgins 1984, 1986). Dormant season fires, especially in the absence of ungulate grazing, may not be natural or desirable (Howe 1994).

Some grassland bird reviews have recommended increased burning of preserve lands (e.g. Knopf 1988 in North America), while others consider intensive burning a threat to grassland birds (e.g. Fitzherbert and Baker-Gabb 1988 in Australia). European conservationists usually recommend (unintensive) traditional farming practices, especially grazing, for conserving grassland birds and other species (Beintema 1988, Hopkins 1991, van Dijk 1991, Kirby 1992). Successful grassland conservation has been known to benefit many species including numerous rare insects (van Dijk 1991).

South-western Missouri (Figure 1) is one of the few regions in the U.S.A. where conservation agencies use considerable haying for managing prairie preserves. This management was developed in part to benefit the Greater Prairie-Chicken Tympanuchus cupido (Solecki and Toney 1986). This study used bird observation rates from Missouri prairies managed in several different ways to learn which management maintained denser populations of these three declining species of sparrows.

\section{Methods}

\section{Study area}

The area between Joplin and Sedalia in south-western Missouri, centred on a point $150 \mathrm{~km}$ SSE of Kansas City, contains more than 50 public prairie preserves (Toney 1993). This area has a temperate climate, with hot summers and cool winters, and an average of $105 \mathrm{~cm}$ of precipitation per year. The 42 study sites $\left(37.02-38.55^{\circ} \mathrm{N}\right.$ and $93.13-95.93^{\circ} \mathrm{W}$ ) are preserves with 6-571 ha (mean $206 \pm 200 \mathrm{ha}$, median $121 \mathrm{ha}$ ) of prairie. Prairies were classified by the management used in 1991-95 ("management type"): 24 prairies were hayed in summer (late June-late July) every 1-3 years ("hay"), seven sites were burned on an approximately 1.5-4 year cycle ("fire"), and 16 sites were hay prairies that were also burned about as intensively as fire prairies, typically but not 


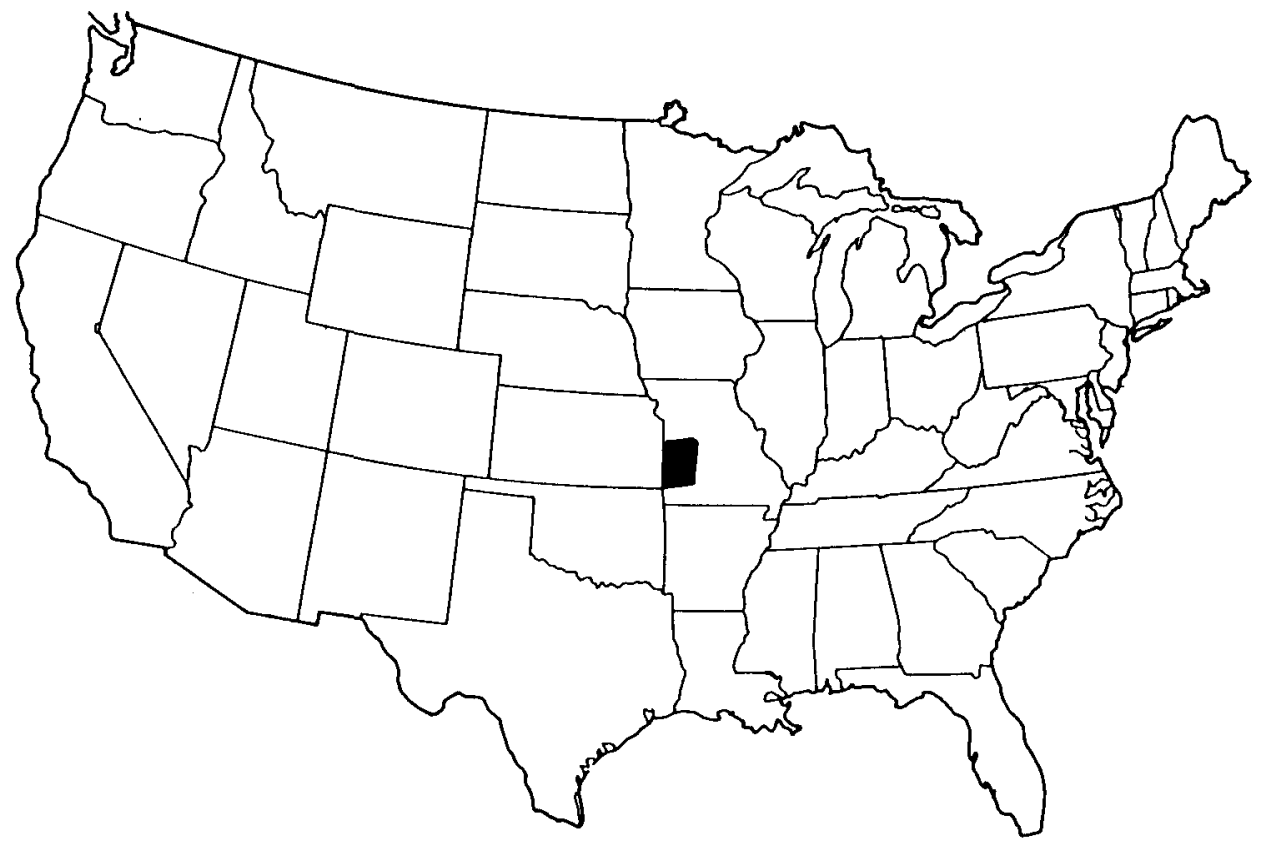

Figure 1. The study area, in black, in south-western Missouri, central U.S.A.

always having more intensive management than either hay or fire prairies ("fire+hay"). Five prairies had two parts classified as different management types. Nearly all management fires occur in March or April (Solecki and Toney 1986).

Hay prairies were hayed an average of every 2.04 years, with $50 \%$ of most prairies hayed per year; the rotation slowed from about 1.8 in 1992-93 to about 2.38 years in 1995. Fire prairies were burned an average of every 2.5 years, varying from $5-100 \%$ of the prairie burned in a year. Fire thay prairies received the most frequent management: they were burned an average of every $2.5-3.0$ years and hayed an average of every 2.5-3.0 years, averaging either a fire or a haying every 1.4 years.

\section{Transects}

While walking at a rate of $1.5^{-2} \mathrm{~km} / \mathrm{hr}$, singing Henslow's Sparrows were counted during 14-24 June in 1992-95, and Grasshopper Sparrows and Dickcissels in 1993-95, in unlimited width transects (Emlen 1971). Transects were conducted once per year at each site and followed similar routes. A new transect unit began each time the prairie vegetation type changed, the management type changed, or the year of last haying or burning changed along the route. Sparrows off the preserve or outside the unit being surveyed were not counted.

Treatments occurring less than one year ago were classified as o years ago and were in their first growing season since treatment, treatments 1-1.99 years ago were called 1 year ago (and were in their second growing season since treatment), and so on. Habitat variables included prairie type (after Toney 1993) 
(wet, 1; wet-mesic, 2; mesic. 3; dry-mesic, 4; dry, 5) and floristic quality (degraded, 1; semi-degraded, 2; undegraded, 3). Floristic quality was based on amount of woody and weedy invasion and diversity of native prairie flora, and agreed with site descriptions by Skinner et al. (1984), The Nature Conservancy (1991) and Toney (1993). Prairies were "diverse" $(=2)$ if they included prairie types that were both drier and wetter than mesic, and "uniform" (=1) if they lacked this combination. To increase sample sizes, surveys were conducted at all times of day from $06 \mathrm{~h} 30$ to $18 \mathrm{~h} 30$ Standard Time. Kantrud (1981) found little variation in grassland bird singing rates by time of day.

\section{Data analysis}

Unweighted observation rates (mean $\pm \mathrm{SD} / \mathrm{km}$ ) were analysed for each bird, and for the three species summed, in a stepwise regression (methods and validity reviewed by Sauer and Droege 1990). Before statistical analysis all bird rates were $\log$-transformed $\left[\log _{\mathrm{e}}(1+\right.$ rate $\left./ \mathrm{km})\right]$. Sixteen variables were tested: year, two time of day measures (see below), wind speed, percentage of time the sun was shining, temperature, latitude, longitude, prairie size, prairie type, prairie diversity, floristic quality, management type, years since haying or burning (whichever value was smaller), and rates of each of the other two species of sparrows. The three species of sparrows summed ("total sparrows") were tested versus 14 independent variables, but not the three individual sparrow species. Other bird rates were tested as independent variables in regressions because they might explain more of a taxon's variation. The stepwise regressions were also run with all variables except the other bird rates.

All variables except time of day and management type had obvious progressions from low to high. ANOVA of bird rates in four different periods of the day (o6h3o-ogh3o, 19h3o-12hoo, 12hoo-14h3o, 14h3o-18h3o) found no temporal effects for any species $(P>0.1)$. Regression of sparrow rates versus time of day ( 24 hour clock) showed a random scatter with $r$ values between -0.07 and 0.08 , and $P>0.15$. Regression was run on a measure of crepuscularity (the length of time between the survey and noon Standard Time) on bird rates, with $r$ values of -0.07 to $0.05(P>0.15)$. Although there was no evidence that time of day affected singing rates (12 tests, all $P>0.1$ ), the time of day and crepuscularity was kept in the stepwise regression because of their possible influence on bird detection.

Management was coded according to its intensity: hay $=1$, fire $=2$, and fire + hay management $=3$. Management treatments on fire thay prairies averaged 1.25-1.5 times more frequent than on hayed or burned prairies. But the management coding scale is not entirely satisfactory, because the effects of fire +hay in some species lie between those seen in hay prairies and fire prairies. To test this, the same regressions were run with the last two management codes reversed: hay $=1$, fire thay $=2$, and fire $=3$.

To test the effects on sparrow abundance of different managements, ANOVA was used to compare mean sparrow rates in hay versus fire sites, hay versus fire +hay sites, and in fire versus fire thay sites. Likewise, sparrow rates were tested versus years since haying and fire using ANOVA. A third analysis used two-way ANOVA to compare sparrow rates versus management types, times 
since management, and interactions of the two management variables. Sparrow rates were also compared versus habitat type with ANOVA. To test whether any of the birds were good indicator species of other declining prairie birds, correlations in rates among the three species of birds were analysed using Pearson's product-moment correlation matrix.

Tests were two-tailed, with statistical significance of simple comparisons set at $P<0.05$. Six of 16 variables never had $P<0.1$ in any regression, so these were dropped and the remaining ten variables were used in the final regressions. The significance level used was $P<0.005$ (0.05/10 variables) for stepwise regressions to minimize Type I statistical errors; because this level makes Type II errors far more likely than Type I, all values with $P<0.05$ are presented. All ANOVAs used Duncan's post-hoc test to correct significance levels to account for multiple comparisons. All statistics were calculated using ABstat 7.20 (Anderson-Bell 1994).

\section{Results}

Henslow's Sparrows were detected on 327 transects totalling $169.1 \mathrm{~km}$, and Grasshopper Sparrows and Dickcissels were detected on 295 transects totalling $134.8 \mathrm{~km}$. All three species were relatively common on the study sites, with 1,193 Henslow's Sparrows, 484 Grasshopper Sparrows, and 1,050 Dickcissels counted on surveys.

\section{Stepwise regression}

Models including rates for other species of sparrows explained more variation in each species's rates than models lacking other species. Therefore, the regressions that included species as independent variables will be presented. It made little difference in the regressions whether management was coded hay = 1 , fire $=2$, and fire thay $=3$, or hay $=1$, fire + hay $=2$, and fire $=3$, since all significant variables were the same, and the coefficients of determination were only $0.00-0.02$ different. The regressions with the highest coefficients of determination were Henslow's Sparrow with fire $=2$, Grasshopper Sparrow and Dickcissel with fire $=2$ or 3 (no difference) and total sparrows with fire $=$ 3. None of the following factors had $P<0.1$ in any regression: year, time of day (both measures), percentage of sunshine, wind speed, and prairie type diversity.

Five variables had significant effects $(P<0.005)$ on Henslow's Sparrow rates (Table 1). Management type was the most important variable, with hay prairies having more Henslow's Sparrows than the fire and fire+hay prairies. Henslow's Sparrows strongly increased with increasing time since last haying or fire, with greater prairie size, more Dickcissels, and toward the south. Nearly significant $(P<0.05)$ factors were longitude and average temperature (negative relationships), and a positive covariance with Grasshopper Sparrows.

Grasshopper Sparrows exhibited a strong positive relationship with prairie dryness and declined with increasing time since last management $(P<0.001)$. Weaker patterns $(P<0.05)$ were preferences for higher floristic quality, positive covariance with Henslow's Sparrows, and an increase to the south. 
Table 1. Results of stepwise regressions of sparrow detection rates by independent variables

\begin{tabular}{|c|c|c|c|c|c|c|c|c|}
\hline \multirow[b]{2}{*}{ Variable } & \multicolumn{2}{|c|}{$\begin{array}{c}\text { Henslow's } \\
\text { Sparrow }\end{array}$} & \multicolumn{2}{|c|}{$\begin{array}{l}\text { Grasshopper } \\
\text { Sparrow }\end{array}$} & \multicolumn{2}{|c|}{ Dickcissel } & \multicolumn{2}{|c|}{$\begin{array}{c}\text { Total } \\
\text { sparrows }\end{array}$} \\
\hline & $r$ & $P$ & $r$ & $P$ & $r$ & $P$ & $r$ & $P$ \\
\hline Full Model & +0.621 & 0.0000 & +0.433 & 0.0000 & +0.445 & 0.0000 & +0.603 & 0.0000 \\
\hline Temperature & -0.127 & 0.0144 & - & - & +0.145 & 0.0105 & - & - \\
\hline Latitude & -0.181 & 0.0022 & - & - & -0.308 & 0.0000 & -0.366 & 0.0000 \\
\hline Longitude & -0.131 & 0.0204 & -0.141 & 0.0135 & - & - & -0.221 & 0.0000 \\
\hline Prairie size & +0.173 & 0.0014 & - & - & +0.250 & 0.0000 & +0.343 & 0.0000 \\
\hline Prairie quality & - & - & +0.137 & 0.0170 & +0.160 & 0.0054 & +0.206 & 0.0000 \\
\hline Prairie type & - & - & +0.228 & 0.0000 & - & - & - & - \\
\hline $\begin{array}{l}\text { Management } \\
\text { type }\end{array}$ & -0.384 & 0.0000 & - & - & - & - & -0.352 & 0.0000 \\
\hline $\begin{array}{l}\text { Years since } \\
\text { management }\end{array}$ & +0.295 & 0.0000 & -0.243 & 0.0000 & - & - & +0.212 & 0.0000 \\
\hline $\begin{array}{l}\text { Henslow's } \\
\text { Sparrow }\end{array}$ & \multicolumn{2}{|c|}{ Not tested } & +0.143 & 0.0187 & +0.171 & 0.0036 & \multicolumn{2}{|c|}{ Not tested } \\
\hline $\begin{array}{l}\text { Grasshopper } \\
\text { Sparrow }\end{array}$ & +0.104 & 0.0465 & \multicolumn{2}{|c|}{ Not tested } & - & - & \multicolumn{2}{|c|}{ Not tested } \\
\hline Dickcissel & +0.163 & 0.0026 & - & - & \multicolumn{2}{|c|}{ Not tested } & \multicolumn{2}{|c|}{ Not tested } \\
\hline
\end{tabular}

Only tests with $P<0.05$ are shown. No tests had $P$ values between 0.05 and 0.1 . Year, time of day, crepuscularity, wind speed, percentage of sunshine, and prairie type diversity never had $P<0.1$. Statistically significant values $(P<0.005$, or $0.05 / 10)$ are in bold type. The first line is the multiple $r$ and probability value of the entire regression. $n=295$ for Henslow's Sparrow and 265 for the other three regressions.

Dickcissels had higher numbers $(P<0.005)$ in larger prairies, more southerly sites, and sites with more Henslow's Sparrows (Table 1). Dickcissels nearly increased significantly with higher floristic quality $(P=0.0054)$.

For total sparrows, six variables had $P<0.001$ (Table 1 ). The three strongest effects were a preference for haying management, a strong preference for large sites, and an increase in numbers to the south. Total sparrows also increased with more time since last management, increasing floristic quality, and toward the east.

\section{Effects of management type}

All three species of sparrows had significantly higher rates in hay prairies than in fire prairies (ANOVA, Table 2): Henslow's Sparrows were 2.04 times

Table 2. Observation rates/km of Henslow's and Grasshopper Sparrows, Dickcissels, and all three summed in south-western Missouri prairies of different management types

\begin{tabular}{|c|c|c|c|c|c|c|c|c|}
\hline \multirow[t]{2}{*}{$\begin{array}{l}\text { Prairie } \\
\text { management }\end{array}$} & \multicolumn{2}{|l|}{$\begin{array}{c}\text { Henslow's } \\
\text { Sparrow }\end{array}$} & \multicolumn{2}{|c|}{$\begin{array}{l}\text { Grasshopper } \\
\text { Sparrow }\end{array}$} & \multicolumn{2}{|l|}{ Dickcissel } & \multicolumn{2}{|l|}{$\begin{array}{c}\text { Total } \\
\text { sparrows }\end{array}$} \\
\hline & Mean $\pm S D$ & $n$ & Mean $\pm S D$ & $n$ & Mean $\pm S D$ & $n$ & Mean $\pm S D$ & $n$ \\
\hline Hay & $10.4 \pm 9.6 \mathrm{~A}$ & 184 & $4.0 \pm 4.8 \mathrm{~A}$ & 171 & $8.5 \pm 6.5 \mathrm{~A}$ & 171 & $23.5 \pm 12.9 \mathrm{~A}$ & 171 \\
\hline Fire & $5.1 \pm 8.3 \mathrm{~B}$ & 55 & $2.5 \pm 6.3 \mathrm{~B}$ & 41 & $7.4 \pm 7.2 \mathrm{~B}$ & 41 & $14.3 \pm 17.4 \mathrm{~B}$ & 41 \\
\hline Fire+hay & $4.1 \pm 7.2 \mathrm{~B}$ & 88 & $3.4 \pm 3.8 \mathrm{~A}$ & 83 & $7.3 \pm 5.6 \mathrm{AB}$ & 83 & $14.7 \pm 10.9 \mathrm{~B}$ & 83 \\
\hline Total & $7.8 \pm 8.8$ & 327 & $3.6 \pm 4.8$ & 295 & $8.0 \pm 6.5$ & 295 & $19.7 \pm 13.7$ & 295 \\
\hline
\end{tabular}

Means for each sparrow followed by different letters are significantly different (ANOVA with Duncan's post-hoc test, $P<0.05)$; means sharing any letters are not significantly different. 
Table 3. Changes in sparrow observation rates $/ \mathrm{km}$ with time since last hay or fire treatment

\begin{tabular}{|c|c|c|c|c|c|c|}
\hline \multirow{2}{*}{$\begin{array}{l}\text { Years since } \\
\text { management }\end{array}$} & \multicolumn{2}{|c|}{ Henslow's Sparrow } & \multicolumn{2}{|c|}{ Grasshopper Sparrow } & \multicolumn{2}{|l|}{ Dickcissel } \\
\hline & Mean $\pm S D$ & $n$ & Mean $\pm S D$ & $n$ & Mean $\pm S D$ & $n$ \\
\hline Hay o & $6.6 \pm 7.2 \mathrm{~A}$ & 126 & $5.4 \pm 5.2 \mathrm{~A}$ & 121 & $8.0 \pm 6.5 \mathrm{~A}$ & 85 \\
\hline Hay 1 & $13.2 \pm 11.0 \mathrm{~B}$ & 64 & $2.2 \pm 2.8 \mathrm{~B}$ & 63 & $9.3 \pm 6.7 \mathrm{~A}$ & 55 \\
\hline Hay 2 & $14.2 \pm 12.5 \mathrm{~B}$ & 18 & $3.7 \pm 2.9 \mathrm{~B}$ & 18 & $7.6 \pm 5.7 \mathrm{~A}$ & 14 \\
\hline Fire o & $1.1 \pm 2.3 \mathrm{~A}$ & 54 & $2.2 \pm 2.6 \mathrm{AB}$ & 48 & $8.0 \pm 5.4 \mathrm{~A}$ & $4^{8}$ \\
\hline Fire 1 & $11.1 \pm 12.3 \mathrm{~B}$ & 20 & $5.4 \pm 9.8 \mathrm{AB}$ & 16 & $6.4 \pm 8.4 \mathrm{~A}$ & 16 \\
\hline Fire 2 & $6.3 \pm 4.1 \quad B$ & 6 & $3.7 \pm 3.0 \mathrm{~A}$ & 6 & $7.1 \pm 6.9 \mathrm{~A}$ & 6 \\
\hline Fire 3 & $5.2 \pm 7.2 \mathrm{AB}$ & 5 & $0.5 \pm 1.1 \mathrm{~B}$ & 5 & $11.3 \pm 5.8 \mathrm{~A}$ & 5 \\
\hline
\end{tabular}

Within each sparrow $X$ management (hay and fire are tested separately), means followed by different letters are significantly different (ANOVA with Duncan's post-hoc test, $P<0.05$ ); means sharing any letters are not significantly different.

$(P<0.001)$, Grasshopper Sparrows 1.59 times $(P<0.01)$, and Dickcissels 1.14 times $(P<0.05)$ as common in hayed sites as in burned sites. Hayed sites had 2.53 times as many Henslow's Sparrows as burned thayed sites $(P<0.001)$; Grasshopper Sparrows and Dickcissels did not differ significantly between these two management types. The only difference between fire and fire+hay was the $34 \%$ higher rate of Grasshopper Sparrows in fire+hay sites $(P<0.01)$. Total sparrows were $60 \%$ more common $(P<0.001)$ in hay prairies than in either fire or fire thay prairies. The lower sparrow rates in fire prairies occurred in spite of the significantly larger size (ANOVA, $P<0.001$ ) of the fire prairies $(347 \pm 249 \mathrm{ha})$ than hay $(190 \pm 182 \mathrm{ha})$ or fire thay $(151 \pm 161 \mathrm{ha})$ prairies, even though two of the three sparrow species increase as prairie size increases (Table 1).

One site experienced three years of light grazing superimposed on the more intensive haying. The grazed segments had very high Henslow's Sparrow (15.8 $\pm 6.6, n=10)$ and Grasshopper Sparrow (4.9 $\pm 3.9, n=9)$ rates, low Dickcissel $(3.3 \pm 2.7, n=9)$ rates, and high total sparrow rates per $\mathrm{km}$ $(23.9 \pm 7.8, n=9)$. The ungrazed part of the prairie had $14.7 \pm 14.9$ Henslow's Sparrows, $4.3 \pm 5.1$ Grasshopper Sparrows, $5.8 \pm 2.7$ Dickcissels, and $24.8 \pm 15.3$ total sparrows per $\mathrm{km}(n=11)$. Sparrow rates in the grazed and ungrazed part of this hay prairie were not significantly different.

ANOVA showed that grazed thay areas had higher Henslow's Sparrow rates than hay only $(P<0.05)$, fire $(P<0.001)$, or fire thay sites $(P<0.001)$; higher Grasshopper Sparrow rates than fire prairies $(P<0.01)$; lower Dickcissel rates than hay $(P<0.01)$ or fire + hay sites $(P<0.05)$; and more total sparrows than fire or fire +hay prairies $(P<0.01)$. These comparisons should be interpreted with caution because all of the grazed units were within one 350 ha prairie.

\section{Duration since last fire or haying}

Henslow's Sparrows increased (ANOVA, $P<0.01$ ) from moderate levels the first growing season after haying (year o) to high levels the second and third season after haying (years 1 and 2) (Table 3), consistent with a strong increase with time since last management indicated by stepwise regression (Table 1). Henslow's 
Table 4. Sparrow observation rates $/ \mathrm{km}$ in different prairie types

\begin{tabular}{|c|c|c|c|c|c|c|c|c|}
\hline \multirow[t]{2}{*}{ Prairie type } & \multicolumn{2}{|l|}{$\begin{array}{l}\text { Henslow's } \\
\text { Sparrow }\end{array}$} & \multicolumn{2}{|c|}{$\begin{array}{c}\text { Grasshopper } \\
\text { Sparrow }\end{array}$} & \multicolumn{2}{|l|}{ Dickcissel } & \multicolumn{2}{|l|}{$\begin{array}{c}\text { Total } \\
\text { sparrows }\end{array}$} \\
\hline & Mean \pm SD & $n$ & Mean $\pm S D$ & $n$ & Mean $\pm S D$ & $n$ & Mean \pm SD & $n$ \\
\hline & $2.7 \pm 3.4 \mathrm{~A}$ & 16 & $0.5 \pm 1.4 \mathrm{~A}$ & 16 & $7.9 \pm 8.6 \mathrm{~A}$ & 16 & $11.1 \pm 11.4 \mathrm{~A}$ & 16 \\
\hline Mesic & $7.1 \pm 8.5 \mathrm{~A}$ & 33 & $1.5 \pm 2.3 \mathrm{~A}$ & 29 & $9.6 \pm 6.7 \mathrm{~B}$ & 29 & $18.7 \pm 12.7 \mathrm{~B}$ & 29 \\
\hline Dry & $8.2 \pm 9.5 \mathrm{~A}$ & 278 & $4.1 \pm 5.0 \mathrm{~B}$ & 250 & $7.8 \pm 6.2 \mathrm{AB}$ & 250 & $20.3 \pm 13.9 \mathrm{~B}$ & 250 \\
\hline
\end{tabular}

For each sparrow, means followed by different letters are significantly different (ANOVA with Duncan's post-hoc test, $P<0.05)$ means sharing any letters are not significantly different.

Sparrows had their lowest rates the first season after fire, increased rapidly by the next year $(P<0.01)$, then levelled out or began dropping again (Table 3 ). Grasshopper Sparrows were 1.6-2.5 times as common in year o after haying as years 1-2 $(P<0.01)$, yet showed a non-significant opposite trend in the corresponding years after fire; they declined between years 2 and 3 after fire $(P<0.05)$ (Table 3). In the regression Grasshopper Sparrows showed a strong negative relationship with time since last management (Table 1 ). Dickcissels exhibited no abundance patterns versus time since the last management treatment (Table 3). Total sparrows increased with time since haying $(P<0.05)$ but did not change with time since fire (Table 3). The regression showed that total sparrows increased with time since last management (Table 1).

\section{Interaction of management and its timing}

Two-way ANOVA of sparrow rates versus both management type and years since last management found significant management type effects for Henslow's Sparrow $(P<0.05)$ and total sparrows $(P<0.001)$ (both were most abundant in hay prairies), and significant effects of years since management for Henslow's Sparrows (increase with time, $P<0.001$ ). Interaction of management type and timing had significant effects for Dickcissels and total sparrows $(P<0.05)$. This interaction in Dickcissels was a result of different abundance patterns with time after treatment in the three management types: they peaked in year 1 in hay prairies, then declined; declined with time since fire in fire prairies; and decreased to a low in year 1 after management before increasing again in fire +hay prairies.

\section{Habitat preferences}

Henslow's Sparrow rates in mesic and dry prairies were about three times as high as in wet prairies, but this difference was not significant (ANOVA, $P>0.05$ ) (Table 4). Grasshopper Sparrows tripled with each step from wet to mesic to dry, and were significantly more common in dry prairies than in either wet $(P<0.001)$ or mesic $(P<0.05)$ prairies $($ Table 4$)$. Dickcissels had higher rates in mesic than dry prairies $(P<0.05)$ (Table 4$)$. Total sparrows were $1.7^{-1.8}$ times as high in mesic and dry prairies as in wet prairies $(P<0.01)$. The non-significant differences in Henslow's and Grasshopper Sparrow rates between wet prairies 
and mesic prairies may be a result of the small sample size of wet prairie transects.

\section{Correlations between species}

Stepwise regressions showed Henslow's Sparrows covarying strongly with Dickcissels $(P<0.005)$ and moderately so $(P<0.05)$ with Grasshopper Sparrows (Table 1). Pearson correlations revealed significant relationships between Henslow's Sparrows and both Grasshopper Sparrows $(r=0.13, n=295, P=$ 0.03) and Dickcissels $(r=0.26, n=295, P<0.001)$.

\section{Discussion}

\section{Habitat preferences}

Detection rates were used to compare relative bird density, but other measures such as nesting success are needed to assess habitat quality fully (Johnson and Temple 1986, Vickery et al. 1992). For example, while twice as many Grasshopper Sparrow nests were found in the burned+grazed part as in the fallow part of an Oklahoma site $150 \mathrm{~km}$ WSW of the study area, nesting success was 2.8 times as high in fallow plots as in burned + grazed (Rohrbaugh 1995).

Henslow's Sparrows, Dickcissels, and total sparrows were more abundant in larger prairies. Area-sensitivity has been documented before for many grassland birds (e.g. Herkert 1994a, Vickery 1994), including Henslow's and Grasshopper Sparrows. Grasshopper Sparrows preferred drier sites, as in other midwestern studies (e.g. Sample 1989). Henslow's Sparrows and Dickcissels lacked strong prairie type preferences. The increase in sparrows to the east could have many causes, for example the increasing moisture and plant productivity to the east.

\section{Management effects}

Hay prairies had the highest rates of all three species of sparrows. Prairie-specialist butterflies also have much higher populations in hayed prairies than in similar fire prairies (Swengel 1996). Like prairie butterflies, these birds had consistently higher numbers and less fluctuation in abundance through the years of the management rotation in hayed prairies than in fire prairies.

Two other south-western Missouri studies found abundant Henslow's Sparrows in unintensively hayed, grazed, or mowed prairies (Skinner 1975, Skinner et al. 1984). Zimmerman (1992) and Herkert (1994b) found low Henslow's Sparrow numbers in frequently burned sites. Henslow's Sparrows avoid nesting in areas burned within the past year (Zimmerman 1988, Rohrbaugh 1995). Grasshopper Sparrows prefer turf heights $<30 \mathrm{~cm}$ high and thrive on light to moderate grazing (Kantrud 1981, Skinner et al. 1984, Smith and Smith 1992), unintensive haying (Skinner 1975), fallow croplands (Johnson and Schwartz 1993), and in burned or unburned prairie (Zimmerman 1992). Dickcissels are not very sensitive to management; they have maintained relatively high numbers in prairies managed by grazing (Skinner et al. 1984), burning or idling (Zimmerman 1992), and haying (this study). 
Time since last haying or fire

Henslow's Sparrows benefitted from longer periods between managements and exhibited 14-fold variation between their low point in year o after fire and their peak several years after haying. The other two species showed much weaker patterns versus time since management. As in Illinois (Herkert 1994b), Henslow's Sparrows in this study were always more common in the hayed or cut year-class than the corresponding fire year-class. Missouri species of Sparrows have high rates sooner after fire or cutting than Upper Midwest sparrows (Huber and Steuter 1984, Volkert 1992, S. Swengel, unpubl. data). This may reflect the faster plant litter accumulation in southern (Missouri) than northern prairies (Kucera and Ehrenreich 1962, Hill and Platt 1975). Henslow's Sparrow, which increases for the longest time post-treatment, prefers the tallest, densest vegetation of the birds studied (Skinner et al. 1984, Smith and Smith 1992).

\section{Conservation recommendations}

Vegetation structure (independent of plant species composition) greatly affects animal densities for many species and management such as grazing that maintains structural diversity promotes overall species richness in grasslands (Hopkins 1991). Henslow's and other sparrows respond strongly to structural features of prairies (Skinner et al. 1984, Zimmerman 1988, 1992; Sample 1989). In this study, moderate to high numbers of all three species were favoured by one management type, haying on a 1-3 year rotation (versus fire). However, wet or mesic prairies regain pre-fire litter levels in 1-3 years, versus $4-6$ years for dry prairies (Henderson 1982) and sooner in southern than northern prairies. This variation in litter build-up rates and their effects on animals should be carefully considered when choosing the intervals between prairie management treatments.

Management that favours Henslow's Sparrows is likely to be adequate but not optimal for Grasshopper Sparrows and Dickcissels. Henslow's Sparrow is the rarest and most specialized of the three (Kahl et al. 1985, Zimmerman 1988). Rates from North American BBS routes where the species was present document a 590:250:1 ratio of Dickcissels: Grasshopper Sparrows : Henslow's Sparrows detected (calculated from Peterjohn et al. 1994). Henslow's Sparrows benefit from a 2-3 year haying rotation. Because Henslow's Sparrow is far rarer than the other species of sparrows, it should receive high management priority.

Conservation haying in south-western Missouri prairies is a sustainable use that raises revenue for conservation agencies and benefits declining prairie birds (this study) and butterflies (Swengel 1996). While spring fires eliminate most nesting cover, conservation haying occurs in July and allows adequate cover for the majority of each bird nesting season before part of the prairie is hayed; regrowth from parts hayed the previous July provides substantial nesting cover (Solecki and Toney 1986). This haying contrasts strongly with standard hay farming, where frequent cuts markedly decrease bird nesting success (Bollinger et al. 1990). Besides favouring the birds studied, haying has resulted in higher 
Greater Prairie-Chicken numbers in Missouri than other managements and has successfully maintained all the rare prairie plants known to occur when haying started (Solecki and Toney 1986).

\section{Acknowledgements}

I thank Drs William and Elsa Boyce for partially funding this research. Robert Askins, James Herkert, Chris Mason, Tom Toney, Peter Vickery and John Zimmerman provided helpful comments on earlier drafts of this paper. Tom Toney reviewed the management types of the prairies and provided advice on coding them. I especially thank Ann Swengel, who put the transect and habitat information in a database and provided much encouragement and advice.

\section{References}

Anderson-Bell (1994) ABSTAT user manual, version 7.20. Arvada, Colorado: Anderson-Bell.

Beintema, A. J. (1988) Conservation of grassland bird communities in The Netherlands. Pp. 105-111 in P. D. Goriup, ed. Ecology and conservation of grassland birds. Cambridge, U.K.: International Council for Bird Preservation (Techn. Publ. 7).

Bollinger, E. K., Bollinger, P. B. and Gavin, T. A. (1990) Effects of hay-cropping on eastern populations of the Bobolink. Wildl. Soc. Bull. 18: 142-150.

Butcher, G. (1989) Bird conservation: establishing priorities. Birdscope 3(1): 1-3.

Collar, N. J. and Andrew, P. (1988) Birds to watch: the ICBP world check-list of threatened birds. Cambridge, U.K.: International Council for Bird Preservation (Techn. Publ. 8).

Emlen, J. T. (1971) Population densities of birds derived from transect counts. Auk 88: 323-342.

England, R. E. and DeVos, A. (1969) Influence of animals on pristine conditions on the Canadian grasslands. J. Range Mgmt, 22: 87-94.

Fitzherbert, J. C. and Baker-Gabb, D. J. (1988) Australasian grasslands and their threatened avifauna. Pp. 227-250 in P. D. Goriup, ed. Ecology and conservation of grassland birds. Cambridge, U.K.: International Council for Bird Preservation (Techn. Publ. 7).

Fretwell, S. (1973) The regulation of bird populations on Konza Prairie: the effects of events off the prairie. Pp. $71-76$ in L. C. Hulbert, ed. Third midwest prairie conference proceedings. Manhattan: Kansas State University.

Hands, H. M., Drobney, R. A. and Ryan, M. R. (1989) Status of the Henslow's Sparrow in the northcentral United States. Twin Cities, Minnesota: U.S. Fish and Wildlife Service.

Henderson, R. (1982) Vegetation - fire ecology of tallgrass prairie. Nat. Areas J. 2(3): 17-26.

Herkert, J. R. (1994a) The effects of habitat fragmentation on midwestern grassland bird communites. Ecol. Appl. 4: 461-471.

Herkert, J. R. (1994b) Status and habitat selection of the Henslow's Sparrow in Illinois. Wilson Bull. 106: 35-45.

Higgins, K.F. (1984) Lightning fires in North Dakota grasslands and in pine-savanna lands of South Dakota and Montana. J. Range Mgmt. 37: 100-103.

Higgins, K.F. (1986) Interpretation and compendium of historical fire accounts in the northern Great Plains. Washington, D.C.: U.S. Fish and Wildlife Service (Resource Publication 161). 
Hill, G. R. and Platt, W. J. (1975) Some effects of fire upon a tall grass prairie plant community in northwestern Iowa. Pp. 103-113 in M. Wali, ed. Prairie: a multiple view. Grand Forks, U.S.A.: University of North Dakota.

Hopkins, J. J. (1991) Management of semi-natural lowland dry grasslands. Pp. 119-124 in P. D. Goriup, L. A. Batten and J. A. Norton eds. The conservation of lowland dry grasslands in Europe. Peterborough, U.K.: Joint Nature Conservation Council.

Howe, H. F. (1994) Managing species diversity in tallgrass prairie: assumptions and implications. Conserv. Biol. 8: 691-704.

Huber, G. E. and Steuter, A. A. (1984) Vegetation profile and grassland bird response to spring burning. Prairie Nat. 16: 55-61.

Hulbert, L. C. (1973) Management of Konza Prairie to approximate pre-white man influences. Pp. 14-19 in L. C. Hulbert, ed. Third midwest prairie conference proceedings. Manhattan, U.S.A.: Kansas State University.

Illinois Natural History Survey (1983) The declining grassland birds. Illinois Nat. Hist. Surv. Notes 227: 1-2.

Johnson, D. H. and Schwartz, M. D. (1993) The Conservation reserve program: habitat for grassland birds. Great Plains Res. 3: 273-295.

Johnson, R. G. and Temple, S. A. (1986) Assessing habitat quality for birds nesting in fragmented tallgrass prairies. Pp. 245-249 In J. Verner, M. L. Morrison and C. J. Ralph, eds. Wildlife 2000: modeling habitat relationships of terrestrial vertebrates. Madison, U.S.A.: University of Wisconsin.

Kahl, R. B., Baskett, T. S., Ellis, J. A. and Burroughs, J. N. (1985) Characteristics of summer habitats of selected nongame birds in Missouri. Missouri Agric. Exp. Sta. Res. Bull. 1056.

Kantrud, H. A. (1981) Grazing intensity effects on the breeding avifauna of North Dakota native grasslands. Canadian Field-Nat. 94: 404-417.

Kirby, P. (1992) Habitat management for invertebrates: a practical handbook. Sandy, Bedfordshire, U.K.: Royal Society for the Protection of Birds.

Knopf, F. L. (1988) Conservation of steppe birds in North America. Pp. 27-41 in P. D. Goriup, ed. Ecology and conservation of grassland birds. Cambridge, U.K.: International Council for Bird Preservation (Techn. Publ. 7).

Knopf, F. L. (1995) Declining grassland birds. Pp. 296-298 in E. T. LaRoe, G. S. Farris, C. E. Puckett, P. D. Doran, and M. J. Mac., eds. Our living resources. Washington, D.C.: National Biological Service.

Kucera, C. L. and Ehrenreich, J. H. (1962) Some effects of annual burning on central Missouri prairie. Ecology 43: 334-336.

McNaughton, S. J. (1985) Ecology of a grazing ecosystem: the Serengeti. Ecol. Monogr. 55: 259-294.

Peterjohn, B. G., Sauer, J. R. and Link, W. A. (1994) The 1992 and 1993 summary of the North American breeding bird survey. Bird Popul. 2: 46-61.

Peterjohn, B. G., Sauer, J. R. and Orsillo, S. (1995) Breeding bird survey: population trends $1966-92$. Pp. 17-21 in E. T. LaRoe, G. S. Farris, C. E. Puckett, P. D. Doran, and M. J. Mac. Our living resources. Washington, D.C.: National Biological Service.

Rohrbaugh, R. (1995) Tallgrass prairie study yields preliminary findings. The Sutton Newsletter 6(winter): 11-13.

Russell, E. W. B. (1983) Indian-set fires in the forests of the northeastern United States. Ecology 64: 78-88.

Sample, D. W. (1989) Grassland birds in southern Wisconsin: habitat preference, population trends, and response to land use changes. M.Sc. thesis, University of Wisconsin, Madison, U.S.A.

Sauer, C. (1950) Grassland climax, fire and management. J. Range Mgmt. 3: 16-20. 
Sauer, J. R. and Droege, S., eds. (1990) Survey designs and statistical methods for the estimation of bird population trends. Washington, D.C.: U.S. Fish \& Wildlife Service (Biol. Rep. 9o(1)).

Sibley, C. G. and Monroe, B. L. Jr. (1990) Distribution and taxonomy of birds of the world. New Haven, U.S.A.: Yale University Press.

Skinner, R. M. (1975) Grassland use patterns and prairie bird populations in Missouri. Pp. 171-18o In M. K. Wali, ed. Prairie: a multiple view. Grand Forks, U.S.A.: University of North Dakota.

Skinner, R. M., Baskett, T. S. and Blenden, M. D. (1984) Bird habitat on Missouri prairies. Jefferson City, U.S.A.: Missouri Dept. of Conservation (Terrestrial Ser. 14).

Smith, D. J. and Smith, C. R. (1992) Henslow's Sparrow and Grasshopper Sparrow: a comparison of habitat use in Finger Lakes National Forest, New York. Bird Obs. 20: 187-194.

Solecki, M. K. and Toney, T. (1986) Characteristics and management of Missouri's public prairies. Pp. $168-171$ in G. K. Clambey and R. H. Pemble, eds. Proceedings ninth North American prairie conference. Fargo, North Dakota, U.S.A.: Tricollege University Center for Environmental Studies.

Swengel, A. B. (1996) Effects of fire and hay management on abundance of prairie butterflies. Biol. Conserv. (76: 73-85).

The Nature Conservancy (1991) Discover natural Missouri. St. Louis, U.S.A.: The Nature Conservancy.

Toney, T. E. (1993) Public prairies of Missouri. Jefferson City, U.S.A.: Missouri Department of Conservation.

van Dijk, G. (1991) The status of semi-natural grasslands in Europe. Pp. 15-36 in P. D. Goriup, L. A. Batten and J. A. Norton eds. The conservation of lowland dry grasslands in Europe. Peterborough, U.K.: Joint Nature Conservation Council.

Vickery, P. D. (1994) Effects of habitat area on the distribution of grassland birds in Maine. Conserv. Biol. 8: 1087-1097.

Vickery, P. D., Hunter, M. L. Jr and Wells J.V. (1992) Is density an indicator of breeding success? Auk 109: 706-710.

Volkert, W. R. (1992) Response of grassland birds to a large-scale prairie planting project. Passenger Pigeon 54: 191-196.

Zimmerman, J. L. (1988) Breeding season habitat selection by the Henslow's Sparrow (Ammodramus henslowi). Wilson Bull. 100: 17-24.

Zimmerman, J. L. (1992) Density-independent factors affecting the avian diversity of the tallgrass prairie community. Wilson Bull. 104: 85-94.

SCOTT R. SWENGEL

9o9 Birch Street, Baraboo, Wisconsin 53913, U.S.A. 